\title{
Characterization of a recent malaria outbreak in the autonomous indigenous region of Guna Yala, Panama
}

\author{
José E. Calzada ${ }^{1}$, Ricardo Marquez², Chystrie Rigg ${ }^{1}$, Carlos Victoria ${ }^{3}$, Manuel De La Cruz², Luis F. Chaves ${ }^{4,5}$ \\ and Lorenzo Cáceres ${ }^{2^{*}}$
}

\begin{abstract}
Background: This study aims to describe the epidemiological and entomological factors associated with a recent malaria outbreak that occurred in 2012 in a socially marginalized population from Guna Yala Comarca in Panama.

Methods: A descriptive and observational study was conducted by analysing demographic and epidemiological data from all malaria cases registered during 2012 in the Comarca Guna Yala, Panama. Malaria intensity indicators were calculated during the study period. Entomological evaluations were performed monthly, from October to December 2012, in the three communities that presented the most intense malaria transmission during the first semester of 2012. Anopheles breeding habitats were also characterized.

Results: During the studied period, 6754 blood smears were examined (17.8\% of the total population), and 143 were confirmed as positive for Plasmodium vivax. A significant increase of malaria transmission risk indicators (API: 3.8/1000, SPR: $2.1 \%$ ) was observed in Guna Yula, when compared with previous years, and also in comparison with estimates from the whole country. Anopheles albimanus was the most abundant and widespread ( $877 ; 72.0 \%)$ vector species found in the three localities, followed by Anopheles punctimacula $(231 ; 19.0 \%)$ and Anopheles aquasalis (110; $9.0 \%)$. Three An. albimanus pools were positive for P. vivax, showing an overall pooled prevalence estimate of 0.014 .

Conclusions: Data analysis confirmed that during 2012 a malaria epidemic occurred in Guna Yala. Panama. This study provides baseline data on the local epidemiology of malaria in this vulnerable region of Panamá. This information will be useful for targeting control strategies by the National Malaria Control Programme.
\end{abstract}

Keywords: Malaria, Plasmodium, Anopheles, Guna Yala, Panama

\section{Background}

As Panamá experiences one of the largest economic growth in Latin America and engages in a national malaria elimination initiative $[1,2]$, the country still faces a major challenge in controlling malaria transmission among socially marginalized populations [3]. The worst case is that of the 'Comarcas': special administrative regions that serve as reservations for Panamanian citizens of Native American descent [4]. These regions

\footnotetext{
*Correspondence: Icaceres@gorgas.gob.pa

${ }^{2}$ Departamento de Entomología Médica, Instituto Conmemorativo

Gorgas de Estudios de la Salud, Panama, Panama

Full list of author information is available at the end of the article
}

and their inhabitants never benefited from sanitation achievements related to the construction of the Panamá Canal and the subsequent development of Panamá [3]. For example, although only $12 \%$ of the total Panamanian population inhabits these reservations, nearly $90 \%$ of the malaria cases in Panamá were reported in these areas during the past decades [1]. Guna Yala, on the Caribbean coast of northeast Panamá is among the poorest regions in Panama, with alarming social and health inequalities compared with other Panamanian provinces [5]. For instance, the multidimensional poverty index (a comprehensive international measurement of acute poverty) was $14.1 \%$ nationwide, but it was $82.3 \%$ in Guna Yala [6]. But more generally, Guna Yala also lags behind in other 
components of social well-being. For example, it has one of the lowest literacy rates in the country and restricted access to health services [6-8]. Guna Yala's economy is mainly based on the exchange of subsistence goods, but tourism is now becoming an important part of the economy [6]. More recently, due to its relative geographical isolation the area has been used as an important transit route for illicit South American drugs on their way to US markets [9]. Similarly, the geographical isolation of this region has been a major obstacle to initiate and sustain effective malaria control activities [1]. For example, most communities from this region, where malaria transmission has been reported during the past decade, can be reached only by boats. Other factors, such as languages barriers, a lack of intercultural understanding and political commitment, further complicate any control effort aimed at the Gunas: the main ethnic group in the region, and the one bearing the largest malaria burden in Panamá [3]. All of these factors have resulted in a poor knowledge of the local malaria epidemiology and historical transmission patterns in Guna Yala. In addition, limited evaluation of the currently applied interventions for malaria vector control has been applied in this region.

This study aims to describe the epidemiological and entomological factors associated with a recent malaria outbreak in the Guna Yala Comarca that occurred in 2012. The study also discusses the effectiveness of current control activities executed by the National Malaria Control Programme (NMCP) in this area of Panamá.

\section{Methods}

\section{Study site and population}

A descriptive and observational study was conducted in the Guna Yula Amerindian autonomous Comarca, located on the Caribbean coast of northeast Panamá, bordering Colombia to the east (Fig. 1). The Guna Yala Comarca comprises around 300,000 ha of continental forest and adjacent coastal waters, including approximately $480 \mathrm{~km}$ of coastline surrounded by reefs and mangroves, and around 365 small coral islands, whose ecology has been heavily modified by anthropogenic influence [10]. Previous rainforest, lowland areas on the coastline are now used by Guna people to grow coconuts and other crops, favouring the presence of Anopheles spp. mosquito breeding sites.

Guna Yala is politically sub-divided into four corregimientos (counties) with 49 comunidades (communities) officially recognized, most of which are located on islands near the mainland coast. Each community has its own political organization represented by a political and spiritual leader called 'Sahila', and the region as a whole is governed by the Guna General Congress [4]. The mean annual temperature, relative humidity and rainfall in Guan Yala are $26.0-27.0{ }^{\circ} \mathrm{C}, 78.0-90.0 \%$ and $1600-3000 \mathrm{~mm}$, respectively [11]. The region of Guna Yala has normally a unimodal rainfall pattern with a dry season from mid-December to April and a rainy season from May to mid-December.

The Gunas have simple lifestyles and maintain their unique traditions. They traditionally sleep in hammocks and their house architecture consists of thatchroofed huts, with earthen floor and walls made of cane sticks vertically lashed to posts with a fibrous plant. In the larger communities huts are organized into straight streets (Fig. 2). This type of houses do not offer much protection against vectors borne diseases.

\section{Malaria indicators and data analysis}

All malaria cases registered during 2012 in Guna Yala, diagnosed by active or passive surveillance performed by the NMCP from Panamá Ministry of Health $(\mathrm{MoH})$ were analysed. Variables considered in the descriptive analysis were: geographical location of cases, sample collection date, diagnosis date, age, gender, ethnicity, parasite species and density, clinical characteristics of cases, socio-economic status of patients, and time between blood sample collection and diagnosis. Since most of the data was recorded at the population level, only descriptive analysis at the population level, that do not quantify the impact of risk factors, were performed. A quantitative logistic regression was not performed due to the lack of individual based data.

An endemic channel was built using as reference the monthly Plasmodium vivax cases registered in Guna Yala in the previous years (2006-2011); 2009 was excluded from this calculation because that year was considered an epidemic year. To estimate the intensity of malaria transmission, the annual blood examination rate (ABER), annual parasite index (API), slide positivity rate (SPR), and the incidence of malaria were also calculated [12]. Demographic and epidemiological data from malaria cases were processed using spreadsheets. Microsoft Excel and Epi Info software were used for analysis. Proportions, central tendency and dispersion measures were calculated.

\section{Entomological evaluation}

Entomological evaluations were jointly performed by the NCMP and Instituto Conmemorativo Gorgas de Estudios de la Salud (ICGES)-trained personnel in the three communities that presented the most intense malaria transmission during the first semester of 2012: Playón Chico $\left(9^{\circ} 18^{\prime} 07.65^{\prime \prime} \mathrm{N} 78^{\circ} 13^{\prime} 29.90^{\prime \prime} \mathrm{W}\right)$, Mamitupo $\left(9^{\circ} 11^{\prime} 24.24^{\prime \prime} \mathrm{N}\right.$ $\left.77^{\circ} 58^{\prime} 24.61^{\prime \prime} \mathrm{W}\right)$ and Achutupo $\left(9^{\circ} 11^{\prime} 52.93^{\prime \prime} \mathrm{N}\right.$ $77^{\circ} 59^{\prime} 13.49^{\prime \prime} \mathrm{W}$ ) (Fig. 1). Collections of immature and adult mosquitoes were performed monthly, from 


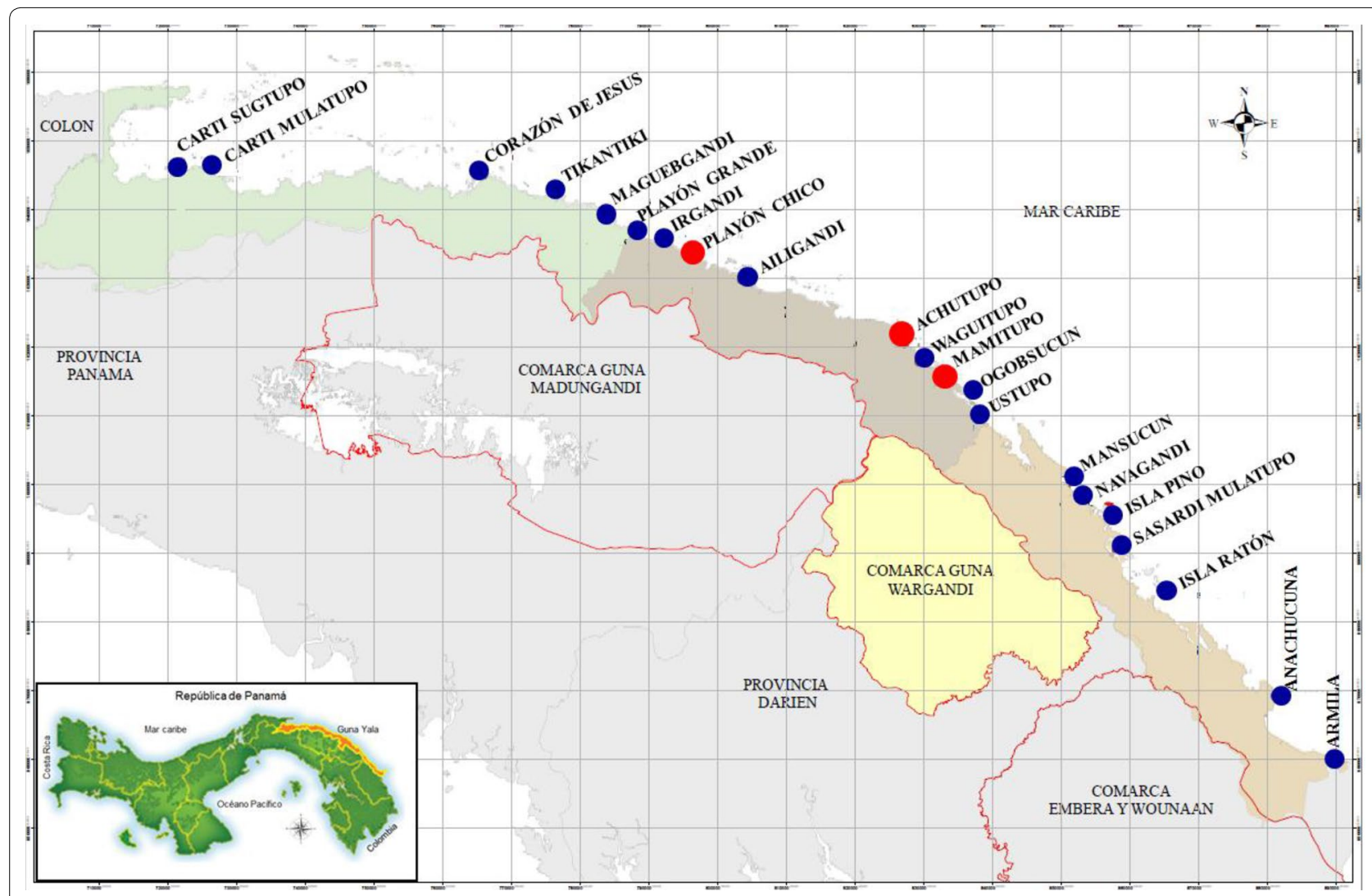

Fig. 1 Communities in Guna Yala Comarca in Panama with malaria cases during 2012. Positive communities where entomological surveys were performed are shown in red circles

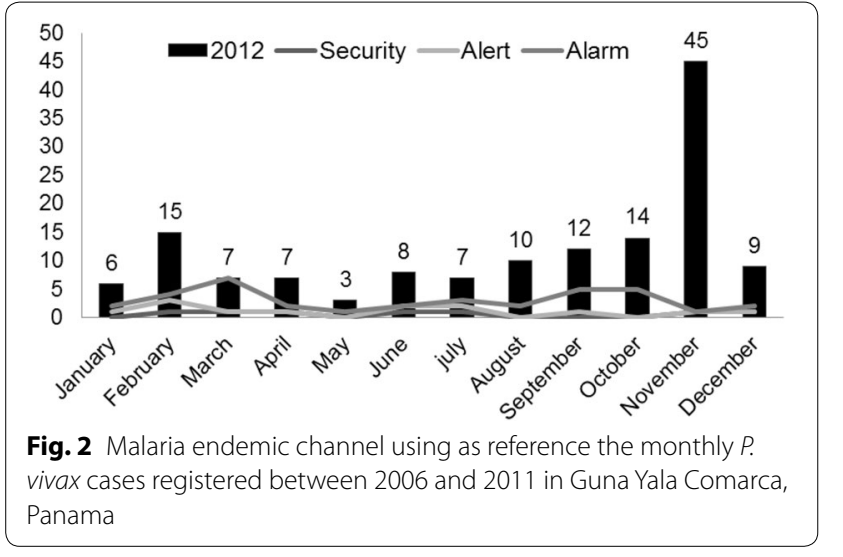

October to December 2012. Anopheles spp. mosquito larvae were collected every month during three consecutive days by the dipping method following WHO guidelines [13]. Collections were performed in suspected natural breeding sites near the communities and households in a radius between 1000 and $1500 \mathrm{~m}$ (Fig. 2). During larval sampling, the environmental characteristics of each habitat were measured and recorded. Direct landing catches (DLC) of Anopheles spp. mosquitoes on humans were performed in the peridomicile from 18:00 to 24:00 $\mathrm{h}$ in each locality, once a month for three consecutive days. To minimize the infection risk, catches were performed by trained collectors, following WHO biosecurity guidelines [13]. Outdoor collections were performed simultaneously using a CDC mini-light trap placed near the breeding sites from 18:00 to $06: 00 \mathrm{~h}$ at $1.5 \mathrm{~m}$. After collection, specimens were placed in labelled cups and transported to the Medical Entomology department at ICGES. Anopheles mosquitoes were morphologically identified using taxonomical keys and the reference collection at ICGES.

For both adult and immature mosquitoes, respectively, the human biting rate per night (HBR) and larval density (larvae/sq $\mathrm{m}$ ) for each species involved in malaria transmission were estimated. To determine the natural infection rates with Plasmodium spp. in Anopheles spp., adult females were grouped by species and locality. According to the date when they were captured, pools of five specimens were processed to extract DNA using a commercial kit (Blood and Tissue ${ }^{\circledR}$ QIAGEN, Hilden, Germany). The presence of Plasmodium DNA was determined with a multiplex-nested PCR as described [14]. 


\section{Ethical statement}

This outbreak investigation was undertaken by the $\mathrm{MoH}$ and ICGES as a joint national surveillance effort to address an immediate and serious threat to public health in Panama. Epidemiological information was obtained from the database available in the NMCP.

\section{Results}

The Guna Yala Comarca has around 37,825 inhabitants distributed in 49 communities, from which 21 (42.8\%) registered malaria cases during 2012 (Fig. 1). Only five of these positive communities were in the mainland. The remainder of the malaria cases were reported in small islands located less than $1 \mathrm{~km}$ from the mainland. During the studied period, 6754 blood smears were examined (17.8\% of the total population), and 143 were confirmed as positive for $P$. vivax. Malaria cases were observed in three of the four counties that conform this region: 95 (66.4\%) in Ailigandi, 28 (19.6\%) in Tubualá and $20(14.0 \%)$ in Nargana. The following communities presented the larger number of cases: Playón Chico (22 cases, $15.4 \%$ ), Playón Grande (21 cases, $14.6 \%$ ), Mamitupo (21 cases, 14.6 \%), Irgandi (ten cases, $7.0 \%$ ), Maguebgandi (ten cases, $7.0 \%$ ), and Navagandi (nine cases, $6.3 \%$ ). Two imported cases (1.4\%) from Colombia were detected, one from the community of Zapzurro and one from Turbo.

An endemic channel was built using as reference the monthly $P$. vivax cases registered in Guna Yala in the previous years, confirming that during 2012 a malaria epidemic occurred in Guna Yala (Fig. 2). During 2012, the months of February (15 cases, $10.5 \%)$, September (12 cases, $8.45 \%$ ), October (14 cases, 9.8.0\%), and November (45 cases, $31.5 \%$ ) registered the highest malaria incidence (Fig. 2). Indicators (ABER, API and SPR) to monitor malaria levels in Guna Yala (2007-2012) are shown in Table 1. During 2012 a significant increase of malaria transmission risk indicators (API: 3.8/1000, SPR: $2.1 \%$ ) was observed in Guna Yula, when compared with previous years, and also in comparison with estimates for the whole country.

During the study period, the median age of malaria cases was 25 years (range 1-74). The under 10 years age group registered the highest number of cases (27.3\%), followed by the 11-20 group (22.4\%) and the 21-30 group (15.4\%) (Table 2). Children under 15 years presented a very high proportional incidence (41.2\%). No cases were recorded in children under 1 year of age. The proportion of male and female cases was similar (51.7 vs $48.3 \%$ ) (Table 2 ).

The parasite density observed in the $P$. vivax cases is shown in Table 3 . It is noteworthy that 23 cases (16.1\%) presented a parasitaemia higher than $6000 / \mu$ l. These parasitaemia levels have been associated with severe malaria and poor prognosis for P. vivax infections [15-17]. However, no severe malaria cases were reported during 2012 in this region. Of the 143 positive patients, 28 (19.6\%) had detectable $P$. vivax gametocytes. Patients with gametocytaemia were mostly under 40 years old (80\%). All cases presented one or more classic signs for $P$. vivax malaria (Table 4). Patients were successfully treated following NMCP guidelines for malaria treatment, and only presented malaria once during 2012.

During the vector survey three predominant types of natural breeding habitats were found, all located in the mainland between 1000 and $1500 \mathrm{~m}$ from the three studied communities. In general, habitats were mainly puddles, coastal lagoons or streams, surrounded by emergent vegetation with full or partial sunlight (Fig. 3). A total of 1120 larvae from three different Anopheles species were collected and identified in the three localities (Table 5). Anopheles albimanus was the predominant vector species with 874 (78.0 \%) specimens, followed by Anopheles punctimacula with158 (14.1\%) and Anopheles aquasalis with 88 (7.9\%). The mean density of larvae collected in the three localities was 8 larvae/sq m (Mamitupo: 11 larvae/sq m; Playón Chico, 7 larvae/sq m; and, Achutupo: 6 larvae/sq m). Detailed estimates by species and location are presented in Table 5. DLC on humans led to the capture of 1218 adult female Anopheles spp. belonging to three species (Table 6). An. albimanus was the most abundant and widespread (877, $72.0 \%$ ), followed by An. punctimacula $(231,19.0 \%)$ and An. aquasalis (110, $9.0 \%)$. The distribution of collected Anopheles spp. mosquitoes by locality and method of collection is shown in Table 6. An. albimanus was the species that exhibited

Table 1 Malaria surveillance indicators in Guna Yala Comarca, Panama, 2007-2012

\begin{tabular}{lllllll}
\hline Malaria indicators & $\mathbf{2 0 0 7}$ & $\mathbf{2 0 0 8}$ & $\mathbf{2 0 0 9}$ & $\mathbf{2 0 1 0}$ & $\mathbf{2 0 1 1}$ & $\mathbf{2 0 1 2}$ \\
\hline Cases & 19 & 21 & 115 & 37 & 34 & 143 \\
API & 0.5 & 0.6 & 3.1 & 1.0 & 0.9 & 3.8 \\
SPR & 0.2 & 0.2 & 0.9 & 0.4 & 0.4 & 2.1 \\
ABER & 26.5 & 27.6 & 33.1 & 22.5 & 22.3 & 17.9 \\
\hline
\end{tabular}

$A P I$ annual parasite index, $S P R$ slide positivity rate, $A B E R$ annual blood examination rate 
Table 2 Distribution of Plasmodium vivax cases by age group and sex registered in Guna Yala Comarca during 2012

\begin{tabular}{lllr}
\hline $\begin{array}{l}\text { Age group } \\
\text { In years }\end{array}$ & Female & Male & Total \\
\hline $0-10$ & 17 & 22 & 39 \\
$11-20$ & 13 & 19 & 32 \\
$21-30$ & 11 & 11 & 22 \\
$31-40$ & 13 & 8 & 21 \\
$41-50$ & 5 & 5 & 10 \\
$51-60$ & 6 & 1 & 7 \\
$>60$ & 4 & 8 & 12 \\
Total & $69(48.3 \%)$ & $74(51.7 \%)$ & 143 \\
\hline
\end{tabular}

Table 3 Parasite density range (parasites/ $\mu$ ) observed in Plasmodium vivax cases from Comarca Guna Yala in Panama during 2012

\begin{tabular}{llc}
\hline $\begin{array}{l}\text { Parasitaemia range } \\
\text { (parasites/ } \boldsymbol{\mu l} \text { ) }\end{array}$ & $\begin{array}{l}\text { Number of } \\
\text { cases (\%) }\end{array}$ & $\begin{array}{l}\text { Accumulated } \\
\text { frequency (\%) }\end{array}$ \\
\hline $1-100$ & $15(10.5)$ & $15(10.5)$ \\
$100-500$ & $21(14.7)$ & $36(25.2)$ \\
$500-1000$ & $16(11.2)$ & $52(36.4)$ \\
$1000-2000$ & $16(11.2)$ & $68(47.6)$ \\
$2000-4000$ & $38(26.6)$ & $106(74.1)$ \\
$4000-6000$ & $14(9.8)$ & $120(83.9)$ \\
$>6000$ & $23(16.1)$ & $143(100)$ \\
\hline
\end{tabular}

Table 4 Signs and symptoms frequencies observed in confirmed Plasmodium vivax cases from Guna Yala Comarca in Panama during 2012

\begin{tabular}{lc}
\hline Signs and symptoms & Frequency (\%) \\
\hline Fever & $140(97.9)$ \\
Chills & $139(97.2)$ \\
Sweats & $128(89.5)$ \\
Headache & $68(47.6)$ \\
Arthralgia & $135(94.4)$ \\
Myalgia & $136(95.1)$ \\
Malaise & $131(91.6)$ \\
Vomiting & $25(17.5)$ \\
Diarrhoea & $49(34.3)$ \\
\hline
\end{tabular}

the highest HBR in the three localities. Mamitupo was the locality with the highest HBR by An. albimanus (15.2 HBR per night) and by An. punctimacula (3.6 HBR per night), displaying a moderate biting rate for these species. Significant differences between HBR for An. albimanus and An. punctimacula were observed in the studied localities (Table 6). In general, HBR showed a peak between
18:30 and 19:30 h. CDC traps in the three localities collected significantly fewer mosquitoes than DLC (Table 6).

To detect Plasmodium infection, 793 adult females were analysed. Forty-four pools from An. albimanus, 11 pools from $A n$. punctimacula and six from An. aquasalis were processed for PCR analysis. Three An. albimanus pools (two from the community of Achutupo and one from Playón Chico) were positive for P. vivax (Fig. 4), showing an overall pooled prevalence estimate of 0.014 . Samples analysed from An. punctimacula and An. aquasalis were negative for Plasmodium spp.

\section{Discussion}

Panamá is one of the eight countries that conformed the Mesoamerica region (Southeast Mexico States and all Central American countries). The significant reduction observed recently in most countries of this region has motivated the launch of an initiative for Malaria Elimination in Mesoamerica and Hispaniola with the active involvement of the National Malaria Control Programmes of nine countries and the support of the Global Fund for Aids, Tuberculosis and Malaria [18]. National political support for this goal was also evidenced by a recent resolution passed by the ministers of health of the Mesoamerican countries as well as the Dominican Republic and Haiti to eliminate malaria by 2020 [19]. Four Mesoamerican countries are currently in the preelimination phase (Mexico, Belize, Costa Rica, and El Salvador). Only Nicaragua and Panamá reported an increase in malaria cases from 2011 to 2012 [20].

The National Malaria Control Programme of Panamá guides and coordinates all malaria control activities in the country [21]. Prevention and control activities are mainly focused on early diagnosis that relies on microscopy and on prompt treatment. Malaria cases are mostly detected by active surveillance performed by NMCP personnel in endemic areas. Health facilities conduct passive case detection without malaria-specific screening centers. These services are free of charge. Chloroquine in combination with primaquine is used for $P$. vivax malaria treatment. Panama is the only country in Central America that recommends artemisinin combined therapy for the treatment of $P$. falciparum infections. Although autochthonous $P$. falciparum infections have not been reported in Panama during the past years, there is an increasing detection of imported cases. Vector control activities routinely performed by the NCMP in Panamá are basically limited to indoor residual spraying (IRS) performed in areas that are considered at risk for malaria transmission based on the malaria incidence observed in previous years. However, due to their traditional beliefs and practices, IRS is still not well accepted by Gunas, with coverage reaching frequently less than $50 \%$ of the households 

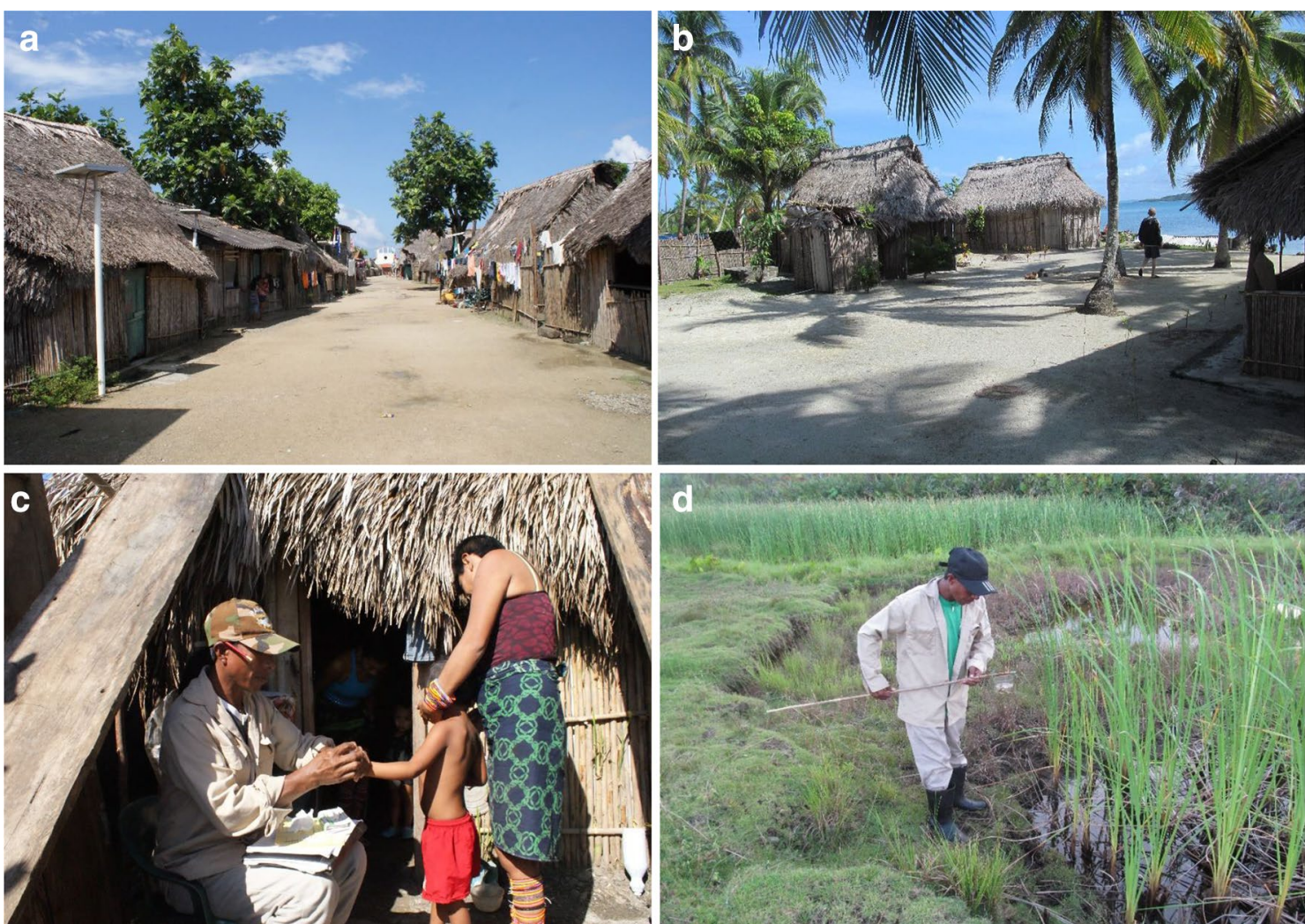

Fig. 3 A malaria endemic community in Guna Yala (Playon Chico) showing traditional thatched homes with earthen floor and cane walls. These houses present typical eaves that facilitate Anopheles mosquito infestation $(\mathbf{a}, \mathbf{b})$. Active malaria case detection performed by NMCP personnel in endemic areas (c). Collection of Anopheles larvae from breeding sites near the community of Playon Chico, Guna Yala (d)

Table 5 Anopheles mosquito larvae collected by species and location in Guna Yala Comarca, Panama, 2012

\begin{tabular}{|c|c|c|c|}
\hline \multirow[t]{2}{*}{ Collected larvae } & \multicolumn{3}{|l|}{ Locality } \\
\hline & Playón Chico & Mamitupo & Achutupo \\
\hline \multicolumn{4}{|l|}{ An. albimanus } \\
\hline Number of larvae & 159 & 480 & 235 \\
\hline Percentage & 18.1 & 55.0 & 26.9 \\
\hline Average (larvae/m²) & 14.0 & 17.0 & 13.0 \\
\hline \multicolumn{4}{|l|}{ An.punctimacula } \\
\hline Number of larvae & 42 & 65 & 51 \\
\hline$\%$ de larvas por & 26.6 & 41.1 & 32.3 \\
\hline Average (larvae/m²) & 3.0 & 3.0 & 2.0 \\
\hline \multicolumn{4}{|l|}{ An. aquasalis } \\
\hline Number of larvae & 41 & 27 & 20 \\
\hline Percentage & 46.6 & 30.7 & 22.7 \\
\hline Average (larvae/m²) & 1.5 & 1.5 & 1.0 \\
\hline
\end{tabular}

in any community [22]. Interestingly, malaria cases were recorded in nine of the 14 communities where IRS was performed during 2012, underlining the need to either
Table 6 Distribution of collected Anopheles spp. mosquitoes by locality and method of collection in Comarca Guna Yala, Panama, 2012

\begin{tabular}{llll}
\hline Adult Anopheles & \multicolumn{2}{l}{ Locality } & \\
\cline { 2 - 4 } & Playón Chico & Mamitupo & Achutupo \\
\hline An. albimanus & 270 & 365 & 242 \\
Relative abundance & 30.8 & 41.6 & 27.6 \\
HBR per night & 11.3 & 15.2 & 10.1 \\
CDC traps & 9 & 11 & 8 \\
An. punctimacula & 75 & 87 & 69 \\
Relative abundance & 32.4 & 37.7 & 29.9 \\
HBR per night & 11.3 & 15.2 & 10.1 \\
CDC traps & 8 & 7 & 9 \\
An. aquasalis & 39 & 34 & 37 \\
Abundancia relativa & 35.5 & 30.9 & 33.6 \\
HBR per night & 11.3 & 15.2 & 10.1 \\
CDC traps & 5 & 5 & 7 \\
\hline
\end{tabular}

HBR human biting rate

increase IRS coverage and to identify different control strategies that are accepted by Guna communities. It is also important to evaluate the possible resistance of the 


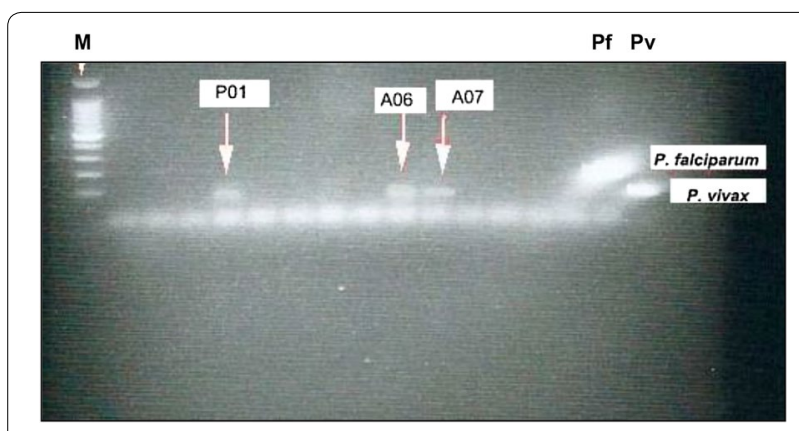

Fig. 4 Nested PCR to detect Plasmodium infection in Anopheles pool samples. M, Molecular size marker (100 bp ladder); P01, A06 and A07, P. vivax positive pool samples; Pf, P. falciparum positive control; $\mathrm{PV}, P$. vivax positive control

local vectors to the insecticides currently used by the NMCP, an activity that is not systematically performed in the country for malaria or any other vector-borne diseases. Fogging with deltamethrin is occasionally used as a vector control intervention during epidemics [21].

Malaria control in border areas has been a challenge for the NMCP in Panamá. In fact, malaria transmission is currently focused in two regions near the borders that together occupy $38.6 \%$ of the country's territory. The eastern focus, close to the border with Colombia, is represented by the indigenous Comarcas of Guna Yala, Madungandí and Wargandi, and the province of Darien. The western focus, close to the border with Costa Rica, is represented by the province of Bocas del Toro and the Comarca of Ngäbe Bugle.

From 1965 to 2012, $8.9 \%$ of the total malaria cases in Panamá were reported in Guna Yala. In this region malaria transmission is considered epidemic-prone, associated with the movement of infected Gunas across the region, as well as the frequent presence of temporal immigrants from endemic-malaria areas in South America [3, 23]. Once malaria is established in Guna Yala, the culturally driven migrations of the Gunas favour the spread of the disease to other indigenous regions of the country occupied by this ethnic group, such as Wargandi and Madungandi in the eastern half of Panamá [3].

Most communities in Guna Yala are highly vulnerable to malaria transmission, mainly because of the continuous presence of suitable breeding habitats for Anopheles near dwellings, which are also mosquito friendly, having no eaves that stop Anopheles spp. infestation [24, 25]. Other risk factors such as destitute housing, which is inappropriate for residual insecticide application [26], and the rejection by the Gunas of different vector control measures, also contribute to the vulnerability of this region [22]. In fact, recent studies have shown that traditional house architecture found in Gunas communities is a risk factor for malaria transmission [23, 27]. In this sense, any effort for housing improvement requires multidisciplinary research, and particularly a multicultural approach that considers the traditional beliefs and practices of Guna communities [22].

During 2012, malaria transmission in this region was continuous. However, the largest number of cases was observed during the last three months of 2012 (Fig. 1), probably associated with rainfall and agricultural, commercial and migration activities that normally increase at the end of the year [28]. In this sense, malaria is perceived as one of the vector-borne diseases more likely to be affected by global climatic changes [29, 30]. For instance, temperature and humidity are factors that affect mosquito longevity and the rate of oogenesis, consequently increasing the potential for malaria transmission [31-33].

It was recently described that changes in climatic variability were significantly related to malaria transmission in the Madungandi Reservation, a region also inhabited by Gunas in Eastern Panama [3]. Due to its location and geographic characteristics (an extended coastline and many inhabited small islands), the Guna Yala region is highly vulnerable to weather-related events. There is strong evidence of an important increase in sea level and a reduction in surface area from uninhabited islands in Guna Yala [10], causing the displacement of some Guna populations from the islands to mainland areas, where there is a higher risk for malaria transmission [4]. This situation highlights the need to study the contribution of climate change in the dynamics of malaria transmission in this vulnerable region from Panamá.

During the past decades the intensity of transmission and the risk of malaria infection have shown significant spatial and temporal fluctuations in Panamá. In this regard, it is important to estimate accurately the malaria burden in each region for an appropriate planning of control interventions, as well as for a more rational allocation of existing resources to control malaria. The API, SPR and ABER are malaria surveillance indicators usually estimated for this purpose $[34,35]$. At the end of 2012, the API in Guna Yala was 3.8/1000 inhabitants, which represents a 4.2 times increase compared with the one observed the previous year $(0.9 / 1000$ inhabitants). In many countries the SPR has been used as a predictor of malaria incidence and as an important indicator to evaluate malaria control programmes [34, 35]. In 2012, the SPR in Guna Yala was very high $(2.1 \%)$ compared with the national statistics of $2012(0.3 \%)$, corresponding to the increase in malaria incidence observed in this region during 2012. The ABER was $17.4 \%$, indicating the examination of a large number of blood smears in search of suspected malaria cases (Table 1). This last indicator estimates the operational efficacy of the NMCP. 
When $P$. vivax cases were stratified by gender, a slight predominance, although not significant, of males over females was found (51.7 vs $48.3 \%$ ). In this region, male Gunas travel from their work to their homes during the first hours of the evening and they also frequently engage in night recreational activities, factors that favour the exposure to infective malaria bites by mosquitoes. It is noteworthy that $90 \%$ of cases were $\leq 40$ years old, and about half (47.6\%) of the cases were in the economically active population, between 15 and 50 years old (Table 2).

Early diagnosis and prompt treatment are crucial factors to consider for malaria control success. Indeed, starting treatment before the appearance of gametocytes is a key strategic point in the interruption of transmission [36]. During the study period, the median time between blood sample collection and thick-smear diagnosis was very high (7 days, range 1-20 days), a factor that most likely was decisive for the high transmission and dispersion of malaria in this region during 2012. In this regard, it is key to highlight the importance of implementing rapid diagnostic tests (RDT) as part of the routine activities of the NMCP, especially during outbreaks occurring in areas of difficult access with scarce health infrastructure, as is the region of Guna Yala. During the past years the MoH of Panama, with the support from PAHO, has undertaken significant efforts to train field personnel and to validate different RDTs available in the market. However, due to legal issues with the Panamanian Medical Technologists Association it has so far not been possible to implement this diagnostic methodology for routine malaria diagnosis by the vector inspectors from the NMCP.

No severe $P$. vivax malaria cases were reported during this period, despite the high parasitaemias observed in many cases. All patients responded adequately to the national standard treatment for vivax malaria [21], and no relapses were recorded during the study period. However, the NMCP believes that within the Guna indigenous population and/or from frequent temporal visitors from South America, there are asymptomatic reservoirs contributing to maintain malaria transmission in the area, a fact that is being reported with growing frequency in Latin America [37]. In this sense, a more comprehensive sampling and the use of more sensitive molecular methods would have been needed to identify asymptomatic infections and determine the real malaria burden in the study area during the epidemic.

In the line with previous studies conducted in Panama [38, 39], An. albimanus was by far the predominant species in the study area, exhibiting the highest prevalence and HBR in the three localities. It was also the only species found naturally infected with $P$. vivax, confirming the importance of $A n$. albimanus as a major malaria vector in this region of Panamá, and most likely responsible for human malaria transmission during the 2012 epidemic. An. albimanus is a species that breeds in a wide variety of aquatic habitats with several types of vegetation in their habitats $[40,41]$, and is considered a major malaria vector throughout Latin America [42, 43].

Anopheles punctimacula and An. aquasalis were found in much smaller numbers. Both species have been incriminated as secondary vectors of human malaria in Panama [44], and have been previously described at different densities in Guna Yala [38]. An. punctimacula showed preference for shallow waters shaded by coconut palms, breeding characteristics described in earlier studies for this species $[39,42]$. Anopheles aquasalis' breeding sites were mangroves and coastal wetlands. Its abundance has been associated with salinity, the presence of aquatic vegetation and permanent breeding sites [45-47]. An. aquasalis has a restricted distribution in Panamá, being particularly prevalent in Guna Yala [38]. In fact, in some communities of this region it has been reported at higher rates than An. albimanus. Anopheles aquasalis is also considered an important vector of malaria in many countries from Latin America [43]. For these reasons it has been suggested that An. aquasalis may play an important role for local malaria transmission in the study region [38]. However, although An. aquasalis was found in entomological surveys at the three collection sites, it had a low density. Moreover, Plasmodium infection was not detected in this mosquito species, although more detailed entomological studies are necessary to better understand any vectorial role for this species.

It is important to note that many of the inhabited islands in Guna Yala lack fresh water, thus Gunas have settled on those islands that are closest to the mainland. The mainland is where they farm crops, hunt and access water from rivers, while on the islands they live and fish on the ocean [48]. Interestingly, during the study period no breeding sites or infected $A n$. albimanus mosquitoes were found in the inhabited islands. Both were found on mainland about $1.0 \mathrm{~km}$ from the communities.

An important limitation of the entomological evaluation is that Anopheles collections were performed only during the last 3 months of 2012 and when a malaria epidemic was occurring in the region. The entomological findings may, therefore, be biased, complicating their interpretation and comparison with other studies.

During the study period, two imported malaria cases were detected from nearby endemic communities on the Atlantic coast from Colombia, where both P. vivax and Plasmodium falciparum circulate. The frequent movement of Gunas and non-indigenous populations between the Panamá-Colombia border is a constant threat, and was most likely the cause of the introduction in 2002 of 
chloroquine-resistant $P$. falciparum parasites in Guna Yala, that spread to other Guna regions in eastern Panamá $[49,50]$. This possibility has been recently reinforced by the molecular relatedness between Colombian and Panamanian malaria samples. Molecular barcoding and drug-resistant loci profiles suggest a northward movement of drug-resistant $P$. falciparum parasites along the Atlantic coast [51]. The region of Turbo in Colombia, from where one of the imported cases came, deserves special attention as not only $P$. falciparum-resistant parasites circulate in this area, but also clinical resistance of $P$. vivax to chloroquine has been reported [52]. This situation calls for an urgent and efficient cross-border cooperation where both neighbouring countries engage in the elimination process, following the example of the concerted efforts between Costa Rica and Panamá in the western border when dealing with malaria control in the migrating Ngabe-Bugle [3, 39].

\section{Conclusion}

This study provides baseline data on the local epidemiology of malaria in this vulnerable region of Panamá. This information will be useful for targeting control strategies by the NMCP. This study also described some of the complex issues that need to be solved in order to achieve malaria elimination in the context of a highly mobile and marginalized population with strong cultural traditions and beliefs.

\begin{abstract}
Abbreviations
ABER: annual blood examination rate; API: annual parasite index; DLC: direct landing catches; HBR: human biting rate; ICGES: Instituto Conmemorativo Gorgas de Estudios de la Salud; IRS: indoor residual spraying; MoH: Ministry of Health; NMCP: National Malaria Control Programme; PAHO: Pan American Health Organization; RDT: rapid diagnostic test; SPR: slide positivity rate; WHO: World Health Organization.
\end{abstract}

\section{Authors' contributions}

JEC, CV and LC conceived the study and participated in its design and coordination. RM and MDLC carried out the entomological collections and evaluations. CR performed the vector molecular analysis. JEC, LFC and LC analysed and interpreted data, and drafted the manuscript. All authors read and approved the final manuscript.

\section{Author details \\ ${ }^{1}$ Departamento de Parasitología, Instituto Conmemorativo Gorgas de Estu- dios de la Salud, Panama, Panama. ${ }^{2}$ Departamento de Entomología Médica, Instituto Conmemorativo Gorgas de Estudios de la Salud, Panama, Panama. \\ ${ }^{3}$ Programa Nacional de Malaria del Ministerio de Salud, Panama, Panama. \\ ${ }^{4}$ Institute of Tropical Medicine (NEKKEN), Nagasaki University, 852-8523 Sakamoto 1-12-4, Nagasaki, Japan. ${ }^{5}$ Programa de Investigación en Enferme- dades Tropicales (PIET), Escuela de Medicina Veterinaria, Universidad Nacional, Heredia, Costa Rica.}

\section{Acknowledgements}

We thank Cristina Gómez and Josue Young for their input and critical reading of the manuscript. This investigation received administrative and financial support from Gorgas Institute, the Ministry of Health and the Ministry of Economy (Grant: 9940-059) from Panamá.

\section{Competing interests}

The authors declare that they have no competing interests. JEC and LC are members of the Sistema Nacional de Investigación (SNI), SENACYT, Panama.

Received: 10 September 2015 Accepted: 4 November 2015

Published online: 17 November 2015

\section{References}

1. Ministerio de Salud de Panamá. Análisis de la Situación de Salud, Panamá. 2015.

2. Panama GDP. Annual Growth Rate 2010-2015. http://www.tradingeconomics.com/panama/gdp-growth-annua. Accessed 12 Aug 2015.

3. Hurtado LA, Cáceres L, Chaves LF, Calzada JE. When climate change couples social neglect: malaria dynamics in Panamá. Emerg Microbes Infect. 2014;3:e27.

4. Martínez Mauri M. La autonomía indígena en Panamá: la experiencia del pueblo kuna (siglos XVI-XXI). SENACYT, Panamá-Editorial Abya Yala, Quito-Ecuador; 2011.

5. Banco Interamericano de Desarrollo. Panamá. Iniciativa salud mesoamericana 2015. http://idbdocs.iadb.org/wsdocs/getdocument. aspx?docnum=36757825. Accessed 12 Aug 2015.

6. PNUD. Atlas del Desarrollo Humano Local Panamá 2015. http://www. pa.undp.org/content/panama/es/home/library/poverty/atlas_desarrollo_humano_local_2015.html. Accessed 2 Aug 2015.

7. Dirección de Estadística y Censo. Encuesta Nacional de Población y Vivienda Panamá. Contraloría General de la República de Panamá, 2011.

8. Dirección de Política Social. [Poverty in Panama': 2003 life level survey.] Panamá: Ministerio de Economía y Finanzas de República de Panamá; 2005.

9. Runk-Velásquez J. Indigenous land and environmental conflicts in Panama: neoliberal multiculturalism, changing legislation, and human rights. J Latin Am Geogr. 2012;11:21-47.

10. Guzmán HM, Guevara C, Castillo A. Natural disturbances and mining of Panamanian coral reefs by indigenous people. Conserv Biol. 2003;17:1396-401.

11. Empresa de Transmisión Eléctrica S. A. Departamento de Hidrometeorología. Estadística Panameña. Situación física. Panamá: ETESA. 2013; p.38.

12. Castillo, CS. Principios epidemiológicos para el control de la malaria. Modulo No. 2. Cuantificación de la malaria como problema de salud. Organización Panamericana de la Salud. 1991; Documento OPS/OMS PNS/90-23(2).

13. Organización Mundial de la Salud. Técnicas entomológicas de campo para la lucha antipalúdica. Parte II. Organización Mundial de la Salud. 1993;54:19-21.

14. Snounou G, Viriyakosol S, Zhu XP, Jarra W, Pinheiro L, do Rosario VE, et al. High sensitivity of detection of human malaria parasites by the use of nested polymerase chain reaction. Mol Biochem Parasitol. 1993;61:315-20.

15. Price RN, Tjitra E, Guerra CA, Yeung S, White NJ, Anstey NM. Vivax malaria: neglected and not benign. Am J Trop Med Hyg. 2007;77(Suppl 6):79-87.

16. Raposo CC, Santos JB, Santos GM, Gonçalves Eda G, Silva AR. Plasmodium vivax malaria: related factors to severity in the State of Maranhão, Brazil. Rev Soc Bras Med Trop. 2013;46:67-72.

17. Naing C, Whittaker MA, Nyunt Wai V, Mak JW. Is Plasmodium vivax malaria a severe malaria?: a systematic review and meta-analysis. PLoS Negl Trop Dis. 2014;8:e3071.

18. Herrera S, Ochoa-Orozco SA, González IJ, Peinado L, Quiñones ML, Arévalo-Herrera M. Prospects for malaria elimination in Mesoamerica and Hispaniola. PLoS Negl Trop Dis. 2015;9:e0003700.

19. Consejo de Ministros de Salud de Centroamérica y República Dominicana (COMISCA), 2013. Declaración-Hacia la eliminación de la malaria en Mesoamérica y la Isla de la Española en el 2020.; COMISCA XROd, editor. San José, Costa Rica.

20. Pan American Health Organization. Interactive Malaria Statistics. http:// www.paho.org/hq/index.php?option=com_content\&view=article\&id= 2632\&ltemid=2130\&lang=en. Accessed 20 Oct 2015.

21. Ministerio de Salud Panamá. Manual de Normas y Procedimientos para Malaria. República de Panamá. Panamá, September 2011. 
22. Cáceres L, Griffith M, Calzada JE, Rovira JE, Torres R. Panamá: Ministerio de Salud, República de Panamá. [Guidelines for the intercultural study of malaria in Comarca Kuna of Madugandi] (in Spanish), 2013.

23. Obaldia N 3rd. Determinants of low socio-economic status and risk of Plasmodium vivax malaria infection in Panama (2009-2012): a case-control study. Malar J. 2015;14:14. doi:10.1186/s12936-014-0529-7.

24. Lindsay SW, Snow RW. The trouble with eaves; house entry by vectors of malaria. Trans R Soc Trop Med Hyg. 1988;82:645-6.

25. Lindsay SW, Emerson PM, Charlwood JD. Reducing malaria by mosquitoproofing houses. Trends Parasitol. 2002;18:510-4.

26. Chaves LF, Calzada JE, Rigg C, Valderrama A, Gottdenker NL, Saldaña A Leishmaniasis sand fly vector density reduction is less marked in destitute housing after insecticide thermal fogging. Parasit Vectors. 2013;6:164. doi:10.1186/1756-3305-6-164.

27. Caceres L, Rovira J, Torres R, Calzada JE, Victoria C, Griffith M. Conocimientos, actitudes y practicas sobre la malaria en la población indigena guna de la Comarca de Madugandi. Biomédica. 2015;35:2386.

28. Sevilla-Casas E. Human mobility and malaria risk in the Naya river basin of Colombia. Soc Sci Med. 1993;37:1155-67.

29. Kovats RS, Menne B, McMichael AJ, Corvalan C, Bertollini R. Climate change and human health: impact and adaptation. Geneva: World Health Organization; 2000.

30. Kuhn K, Campbell-Lendrum D, Haines A, Cox J. Using climate to predict infectious disease epidemics. Geneva: World Health Organization; 2005.

31. Rúa G, Quiñones ML, Vélez ID, Zuluaga JS, Rojas W, Poveda G, et al. Laboratory estimation of the effects of increasing temperatures on the duration of gonotrophic cycle of Anopheles albimanus (Diptera: Culicidae). Mem Inst Oswaldo Cruz. 2005;100:515-20.

32. Afrane YA, Zhou G, Lawson BW, Githeko AK, Yan G. Effects of microclimatic changes caused by deforestation the survivorship and reproductive fitness of Anopheles gambiae in western Kenya highlands. Am J Trop Med Hyg. 2006;74:772-8.

33. Chaves LF, Koenraadt CJ. Climate change and highland malaria: fresh air for a hot debate. Q Rev Biol. 2010;85:27-55.

34. Hay SI, Okiro EA, Gething PW, Patil AP, Tatem AJ, Guerra CA, et al. Estimating the global clinical burden of Plasmodium falciparum malaria in 2007 PLoS Med. 2010;7:e1000290. doi:10.1371/journal.pmed.1000290.

35. Bi Y, Hu W, Liu H, Xiao Y, Guo Y, Chen S, et al. Can slide positivity rates predict malaria transmission? Malar J. 2012;11:117. doi:10.1186/1475-2875-11-117.

36. Hetzel MW, Iteba N, Makemba A, Mshana C, Lengeler C, Obrist B, et al. Understanding and improving access to prompt and effective malaria treatment and care in rural Tanzania: the ACCESS Programme. Malar J. 2007;6:83.

37. Vallejo AF, Chaparro PE, Benavides Y, Álvarez Á, Quintero JP, Padilla J, et al. High prevalence of sub-microscopic infections in Colombia. Malar J. 2015;14:201. doi:10.1186/s12936-015-0711-6.

38. Loaiza JR, Bermingham E, Scott ME, Rovira JR, Conn JE. Species composition and distribution of adult Anopheles (Diptera: Culicidae) in Panama. J Med Entomol. 2008;45:841-51.
39. Cáceres L, Rovira J, Torres R, García A, Calzada J, De La Cruz M. [Characterization of Plasmodium vivax malaria transmission at the border of Panamá and Costa Rica](in Spanish). Biomedica. 2012;32:557-69. doi:10.1590/ S0120-41572012000400011.

40. Mekuria Y, Tidwell MA, Williams DC, Mandeville JD. Bionomic studies of the Anopheles mosquitoes from Dajabon, Dominican Republic. J Am Mosq Control Assoc. 1990;6:651-7.

41. Frederikson EC. Bionomics and control of Anopheles albimanus. Technical Paper No. 34. Washington, DC. Panamerican Health Organization. 1993; p. 76.

42. Rejmánková E, Roberts DR, Harbach RE, Pecor J, Peyton EL, Manguin S, et al. Environmental and regional determinants of Anopheles (Diptera: Culicidae) larval distribution in Belize, Central America. Environ Entomol. 1998;22:978-92.

43. Arevalo-Herrera M, Quiñones ML, Guerra C, Céspedes N, Giron $\mathrm{S}$, Ahumada $\mathrm{M}$, et al. Malaria in selected non-Amazonian countries of Latin America. Acta Trop. 2012;121:303-14. doi:10.1016/j. actatropica.2011.06.008.

44. Darling ST. Isthmian Canal Commission Report. Washington, DC: Studies in relation to malaria. Laboratory of the Board of Health; 1910.

45. Flores-Mendoza C, Lourenço-de-Oliveira R. Bionomics of Anopheles aquasalis Curry 1932, in Guaraí, State of Rio de Janeiro, southeastern Brazil-I. Seasonal distribution and parity rates. Mem Inst Oswaldo Cruz. 1996;91:265-70.

46. Grillet ME. Factors associated with distribution of Anopheles aquasalis and Anopheles oswaldoi (Diptera: Culicidae) in a malarious area, northeastern Venezuela. J Med Entomol. 2000; 37:231-8.

47. Berti J, González J, Navarro-Bueno E, Zoppi E, Gordon E, Delgado L. [Larval seasonality of the mosquito Anopheles aquasalis (Diptera: Culicidae) and other insects associated to its habitat in Sucre, Venezuela](in Spanish). Rev Biol Trop. 2010;58:777-87.

48. Panama Mission Report. The peninsula principles in action. Climate change and displacement in the autonomous region of Gunayala, July 2014 http://displacementsolutions.org/wp-content/uploads/panamathe-peninsula-principles-in-action.pdf.

49. Samudio F, Santamaría AM, Nicanor O III, Pascale JM, Bayard V, Calzada JE. Prevalence of Plasmodium falciparum mutations associated with antimalarial drug resistance in Guna Yala, Panama. Am J Trop Med Hyg. 2005;71:839-41.

50. Calzada JE, Samudio F, Bayard V, et al. Revising antimalarial drug policy in Central America: experience in Panama. Trans R Soc Trop Med Hyg. 2008;102:694-8.

51. Obaldia N 3rd, Baro NK, Calzada JE, Santamaria AM, Daniels R, Wong W, et al. Clonal outbreak of Plasmodium falciparum infection in eastern Panama. J Infect Dis. 2015;211:1087-96.

52. Soto J, Toledo J, Gutierrez P, Luzz M, Llinas N, Cedeño N, et al. Plasmodium vivax clinically resistant to chloroquine in Colombia. Am J Trop Med Hyg. 2001;65:90-3.

\section{Submit your next manuscript to BioMed Central and take full advantage of:}

- Convenient online submission

- Thorough peer review

- No space constraints or color figure charges

- Immediate publication on acceptance

- Inclusion in PubMed, CAS, Scopus and Google Scholar

- Research which is freely available for redistribution

Submit your manuscript at

www.biomedcentral.com/submit
C Biomed Central 